Jurnal Interpretasi Hukum | ISSN: 2746-5047

Vol. 2, No. 3-Desember 2021, Hal. 618-623| Tersedia online di

https://www.ejournal.warmadewa.ac.id/index.php/juinhum

DOI: https://doi.org/10.22225/juinhum.2.3.4155.618-623

\title{
PELAKSANAAN PERJANJIAN KERJA BAGI PEKERJA PKWT DI PT. JAYA ARTHA SYANDANA PADA MASA PANDEMI COVID-19
}

\author{
Komang Krisna Hady Saputra, I Nyoman Putu Budiartha, Ni Made Puspasutari Ujianti \\ Fakultas Hukum, Universitas Warmadewa, Denpasar-Bali, Indonesia \\ Krisnahady17@gmail.com, budiarthaputu59@gmail.com, puspasutariujianti@gmail.com
}

\begin{abstract}
Abstrak
Perjanjian kerja berdasarkan Undang-undang Ketenagakerjaan pada dasarnya sifatnya lebih umum. Sifat umum yang dimaksud karena menunjuk pada hubungan kerja pekerja dan pengusaha yang telah memuat syarat-syarat kerja, hak dan kewajiban para pihak. Dalam membuat perjanjian kerja pada ketentuannya semua sama, yaitu tidak boleh bertentangan dengan peraturan perusahaan, perjanjian kerja bersama, dan peraturan Perundangundangan yang berlaku. Penelitian ini bertujuan mengkaji prosedur pelaksanaan kontrak kerja perusahaan pada waktu tertentu dan mengungkapkan perlindungan hukum bagi karyawan yang diberhentikan oleh perusahaan pada masa pandemi COVID19. Penelitian ini didesain menggunakan penelitian hukum empiris dengan pendekatan perundang-undangan. Bahan hukum primer diperoleh melalui kegiatan wawancara dan data sekunder melalui kegiatan kepustakaan, selanjutnya data diolah dengan analisis deskriptif kualitatif. Hasil penelitian mengungkapkan bahwa apabila dalam suatu perusahaan telah memiliki peraturan kerja bersama isi perjanjian kerja baik kualitas dan kuantitasnya tidak boleh lebih rendah pada peraturan perusahaan atau perjanjian kerja bersama yang telah ada dalam perusahaan yang bersangkutan. Pemutusan hubungan kerja ini berdasarkan ketentuan Pasal 150 Undang-undang RI Nomor 13 Tahun 2003. Pemutusan hubungan kerja memiliki akibat hukum, bagi pengusaha maupun pekerja atau buruh itu sendiri. Akibat hukumnya adalah pengusaha wajib memberikan kompensasi kepada pekerja atau buruh yang diputuskan hubungan kerjanya.
\end{abstract}

Kata Kunci: Covid-19, Kontrak kerja, Pemutusan Hubungan Kerja

\begin{abstract}
Employment agreements based on the Manpower Act are basically more general in nature. The general nature is meant because it refers to the working relationship of workers and employers which has contained the working conditions, rights and obligations of the parties. In making a work agreement, the provisions are all the same, that is, it must not conflict with company regulations, collective labor agreements, and applicable laws and regulations. This study aims to examine the procedures for implementing the company's work contract at a certain time and to reveal legal protection for employees who are dismissed by the company during the COVID19 pandemic. This study was designed using empirical legal research with a statutory approach. Primary legal materials were obtained through interviews and secondary data through library activities, then the data was processed by qualitative descriptive analysis. The results of the study reveal that if a company already has a collective work regulation, the content of the work agreement, both in quality and quantity, should not be lower than that of the company's regulations or the existing collective labor agreement within the company concerned. This termination of employment is based on the provisions of Article 150 of Law of the Republic of Indonesia Number 13 of 2003. Termination of employment has legal consequences, for both employers and workers or the workers themselves. The legal consequence is that employers are obliged to provide compensation to workers or workers whose employment relationship is terminated.
\end{abstract}

Keywords: Covid-19, Employment Contract, Termination of Employment

\section{PENDAHULUAN}

Saat ini, akibat munculnya virus korona baru, sangat berdampak pada perkembangan tren globalisasi, dan kerja sama di berbagai bidang sangat memburuk. Akibat peraturan pemerintah untuk menangani Covid-19, banyak perusahaan yang mengalami penutupan dan banyak pekerja yang mengalami kehancuran pengaturan kerja secara tunggal oleh organisasi (Maslikan \& Sukarmi, 2018). Terlepas dari kenyataan bahwa kontrak bisnis telah dikendalikan oleh organisasi dan perwakilan, terbitnya peraturan ini maka menjadi masalah bagi perusahaan sehingga karyawan menjadi korban pemutusan hubungan kerja (Wahid \& Puspita, 2017) 
PT. Jaya Artha Syandana yang bergerak pada bisnis outsourcing, memiliki lini bisnis pada bidang rekrutmen, manajemen dan pelatihan, dan juga berdampak Covid-19. Salah satunya, data Kementerian Kesehatan tentang lansia tidak boleh melakukan aktivitas berlebihan. PT. Jaya Artha Syandana adalah salah satu dari beberapa karyawan PT. Jaya Artha Syandana dipecat atau diberhentikan (pemutusan hubungan kerja) sebelum masa kontrak kerja berakhir, karena masa pandemi Covid-19 saat ini, karena daya tahan tubuh yang lemah, perusahaan tidak mau mengambil risiko dengan karyawan yang sudah lanjut usia, sehingga virus sangat mudah untuk masuk dan dapat ditularkan kepada keluarga karyawan dan orang-orang terdekat perusahaan. Oleh karena itu, perusahaan memecat beberapa karyawan yang sudah tua atau memiliki riwayat kesehatan, dan karyawan yang dipecat tersebut tidak mau menerima keputusan perusahaan karena sulit ditemukan di masa pandemi ini.

Bagi buruh sendiri, pendekatan pemanfaatan PKWT dianggap kurang menguntungkan mengingat jam kerja yang mereka terima dalam pengaturan tidak akan mempengaruhi cara kerja, kondisi atau kedudukannya sebagai buruh, dan selesainya uang pesangon pada saat kesepakatan tidak disepakati. Meskipun demikian, kenyataannya selama pandemi, organisasi benar-benar memberhentikan beberapa karyawan. Akibatnya jumlah penangguran makin bertambah dan hal ini meningkatkan jumlah orang miskin di negara ini.

Penelitian sebelumnya mengungkapkan bahwa walaupun telah ada payung hukum terhadap karyawan yang bekerja dalam perusahaan yang dimuat dalam Undang-undang ketenaga kerjaaan, namun belum bisa menjamin dan memberi rasa keadilan penuh kepada karyawan (Ramlan \& Fitri, 2020). Penelitian lain mengungkapkan bahwa kontrak kerja berfungsi untuk melakukan evaluasi pekerja yang bersifat tetap guna menguji kemampuan, kualitas kerja, sikap pekerja kontrak sebelum diangkat. Melalui perjanjian kerja ini memuat pernyataan perjanjian secara bersama oleh pihak perusahaan dengan pekerja dalam waktu tertentu biasanya selam satu tahun tergantung perusahaan. Apa bila pihak perusahaan memberhentikan pekkerja tersebut sebelum masa kontrak habis maka perusahaan wajib mengikuti prosedur dengan membayarkan pesangon kepada yang bersangkutan (Dewi et al., 2013) \& (Maslikan \& Sukarmi, 2018). Walaupun sudah banyak kajian terkait kasus pemutusan hubungan kerja secara sepihak, namun diketahui sampai saat ini menjadi masalah serius yang meresahkan karyawan yang menjadi korban PHK secara sepihak tanpa diberikan hak penuh kepada mereka. Berdasarkan fenomena ini, maka ingin melakukan penelitian yang bertujuan untuk mengkaji prosesedur pelaksanaan kontrak kerja perusahaan pada waktu tertentu dan mengungkapkan perlindungan hukum bagi karyawan yang diberhentikan oleh perusahaan pada masa pandemi Covid-19.

\section{METODE PENELITIAN}

Ketika berbicara tentang kasus ini, maka penelitian yang tepat diterapkan adalah penelitian hukum empiris, analisis yang menggunakan fakta empiris yang diperoleh dari sifat manusia, baik yang diperoleh secara lisan melalui wawancara atau peristiwa nyata yang diperoleh melalui pengamatan langsung. Adapu bahan hukum yang digunakan adalah bahan hukum primer dan sekunder yang diperoleh melalui wawancara. Bahan hukum primer meliputi hasil wawancara yang diperoleh dari beberapa pekerja yang menjadi korban PHK dan beberapa arsip surat perjanjian kontrak kerja menjadi bahan utam yang akan dikaitkan dengan UU ketenaga kerjaan. Bahan hukum sekunder yaitu penelitian-penelitian hukum yang mengkaji masalah yang relevan dengan masalah yang sedang diteliti saat ini yang telah dipublis di beberapa jurnal ilmiah. Setelah data hukum semua terkumpul, maka dianalisis dan diolah dengan analisis deskriptif kualitatif (Moleong, 2005).

\section{HASIL DAN PEMBAHASAN}

\section{Pelaksanaan Perjanjian Kerja Terhadap Karyawan dengan Perusahaan}

Kontrak kerja harus memenuhi persyaratan hukum kontrak, seperti Pasal 52 (1) UU Sumber Daya Manusia No. 13 Tahun 2003, pelaksanaan kontrak kerja didasarkan pada:

1. Kedua belah pihak dalam perjanjian.

Kesepakatan antara kedua belah pihak yang biasa disebut dengan kesepakatan kontraktor, artinya kedua belah pihak yang membuat perjanjian kerja harus mencapai kesepakatan/kebulatan suara tentang hal-hal yang telah disepakati. Pekerja menerima pekerjaan yang ditawarkan, dan majikan 
menerima pekerjaan pekerja. Dengan kata lain, tidak ada unsur penipuan ( $d$ wang), paksaan (dwaling) dan pengawasan (bedrog) dalam kesepakatan antara kedua belah pihak.

2. Kemampuan atau keterampilan untuk melakukan tindakan hukum. Kemampuan atau kemampuan kedua belah pihak untuk mencapai kesepakatan berarti baik pekerja maupun pengusaha memiliki kemampuan untuk mencapai kesepakatan. Jika orang tersebut cukup umur, orang tersebut dianggap mampu mencapai kesepakatan. Berdasarkan ketentuan Undang-undang ketenagakerjaan, sesuai dengan ketentuan Pasal 1 ayat 26 Undang-undang Nomor 13 Tahun 2003 tentang Tempat Konstruksi, batas usia minimal bagi orang yang dianggap mampu menandatangani kontrak kerja adalah 18 tahun. Pasal 69 Undang-undang Nomor 13 Tahun 2003 tentang Ketenagakerjaan mengatur bahwa anak-anak yang berusia antara 13 dan 15 tahun dapat melakukan pekerjaan ringan secara luar biasa, sepanjang tidak mempengaruhi perkembangan dan kesehatan fisik, mental, dan sosial. Selain itu dikatakan bahwa jika seseorang tidak berada dalam perwalian yaitu tidak mengalami perubahan atau kesehatan mental, dapat dicapai kesepakatan kerja.

3. Pekerjaan yang disetujui Kehadiran pekerjaan yang disetujui menyiratkan bahwa pengaturan telah dicapai pada masalah tertentu. Pekerjaan yang disepakati adalah subjek dari pemahaman kerja antara visioner atau manajer bisnis dan spesialis atau pekerja, dan hasil yang sah menghasilkan hak dan komitmen kedua pemain.

4. Pekerjaan yang disetujui tidak akan bergumul dengan pengaturan permintaan publik, kehormatan, dan Undang-undang serta pedoman terkait (Sendjun, 2001).

Pada dasarnya objek kontrak (pekerjaan) harus legal, artinya tidak bisa menolak hukum, permintaan publik, dan kualitas yang mendalam. Jika pekerjaan yang disepakati adalah salah satu bagian dari pemahaman bisnis, itu harus diungkapkan dengan jelas. Istilah kehendak kedua pemain itu bebas atau kapasitas pertemuan untuk mencapai suatu pemahaman lebih abstrak, karena mempengaruhi individu yang setuju. Kondisi legitimasi pekerjaan yang disepakati dan pekerjaan yang disetujui harus substansial dan disebut kondisi target karena termasuk objek pemahaman. Dengan asumsi kondisi target tidak terpenuhi, pengaturannya tidak valid, menyiratkan bahwa pemahaman tidak akan pernah ada selama ini. Jika syarat abstrak tidak terpenuhi, perkumpulan tidak memberikan persetujuan dengan sengaja, atau orang tua atau penjaga tidak dapat mencapai kesepakatan, mereka dapat meminta hakim untuk membatalkan kesepakatan. Oleh karena itu, sepanjang tidak dibatalkan oleh hakim, maka perjanjian itu mempunyai kekuatan hukum (Abdul, 2014).

PT. Jaya Artha Syandana memberikan perjanjian kepada karyawan, sebagai berikut:

1. Pihak pertama dengan ini menunjuk pihak kedua sebagai pekerja, dan mengatur Tabanan untuk bekerja atas nama pekerja atau pekerja tidak terampil selama jangka waktu perjanjian ini dalam waktu yang ditentukan, yaitu 11 bulan 25 hari, terhitung mulai tahun 2021. 6 Januari 2021 hingga 31 Desember 2021; sejak pihak kedua menyetujui penunjukan tersebut, maka ia setuju. melewati. Menjadi karyawan bagian pertama dan menerima salah satu atau semua syarat, syarat dan ketentuan kerja dalam perjanjian ini, peraturan perusahaan, dan aturan yang berlaku untuk bagian pertama.

2. Dalam hal pihak utama ingin memperluas pengertian ini, pihak utama akan memberitahukan kepada pihak kedua selambat-lambatnya tujuh hari setelah berakhirnya perjanjian ini.

3. Pihak B berhak atas gaji bulanan sebesar Rp 1.000.000 (Rp 1 juta). Tidak ada potongan pajak untuk upah bulanan, tidak ada potongan pajak untuk BPJS Kesehatan dan Ketenagakerjaan, atau potongan lainnya.

4. Pihak kedua berhak atas tunjangan hari raya (THR) sebesar Rp yang diberikan oleh pihak pertama. 1.000.000, (satu juta rupiah) sebelum hari raya Nyepi.

5. Gaji akan ditransfer ke rekening bagian B setiap akhir bulan atau paling lambat lima (lima) hari di bulan berikutnya. Pihak B akan membuka rekening bank yang ditunjuk oleh Pihak A untuk menutupi pengeluaran mereka.

6. Pengakhiran dan pemutusan perjanjian ini akan mengakibatkan pemutusan dan pemutusan hubungan kerja antara pihak pertama dan kedua secara bersamaan, tanpa keputusan/keputusan lembaga penyelesaian perselisihan manajemen perburuhan, jika salah satu dari berikut ini alasan terpenuhi:

a) Berakhirnya masa kontrak.

b) Sebagian atau seluruh keterangan dalam Pasal (1) adalah palsu. 
c) Pihak A dan Pihak B setuju untuk memutuskan hubungan kerja. Di dalam hari,

d) pihak kedua menentukan kesalahan dalam PT penyebab darurat peraturan perusahaan.

e) Pihak kedua tidak menunjukkan kinerja yang memuaskan dan/atau tidak menjalankan tugasnya secara normal dengan alasan apapun, sehingga tidak mencapai tujuan dan mendapat teguran lisan.

f) Tidak memungkinkan untuk dilaksanakannya keadaan tertentu (force majeure) dari perjanjian kerja ini.

7. Pemutusan hubungan kerja yang telah terjalin adalah pemutusan hubungan kerja tanpa adanya pembayaran pesangon dan/atau balas jasa, kompensasi, jasa dan kompensasi atau kewajiban finansial kepada pihak pertama.Pemutusan hubungan kerja Jika Pihak A memutuskan hubungan kerja dengan Pihak B atau Pihak B dan Pihak A memutuskan hubungan kerja dengan Pihak A tanpa kesalahan apapun sebelum pemutusan kontrak kerja ini, tidak akan ada penalti atau kompensasi. Bagi pihak yang memutuskan hubungan kerja sebelum pemutusan kontrak kerja.

8. Merentangkan interupsi yang dulunya merupakan alternatif yang diperbolehkan kini menjadi pilihan. Kedua pasal ini menunjukkan bahwa posisi negara atas undang-undang ketenagakerjaan semakin berkurang.

9. Hal-hal yang terkait dengan hubungan bisnis, seperti jangka waktu perjanjian, kesimpulan dari persahabatan kerja yang lama, dll, dikembalikan ke kerangka kerja administratif total melalui pemahaman tentang bisnis, asosiasi, atau keseluruhan tindakan kerja, khususnya pekerjaan dan supervisor. aturan. Ini jelas mengurangi keamanan buruh, berpendapat bahwa dalam hubungan yang saling bertentangan antara buruh dan administrator, pemahaman antara buruh dan manajer secara keseluruhan akan merepotkan buruh (wawancara dengan Direktur PT. Jaya Artha Syandana).

\section{Perlindungan Hukum Terhadap Karyawan yang di PHK pada Masa Pandemic Covid-19}

Pada tahun 2020, Pemerintah membuat Undang-undang nomor 11 Tahun 2020 untuk penciptaan lapangan kerja. Salah satu paling akhir memanfaatkan metode ketenagakerjaan yang ditingkatkan disetujui adalah pekerjaan. Perubahan pada beberapa artikel demonstrasi ketenagakerjaan 2003 dinilai merugikan pekerja. Upaya untuk mengurangi atau menghilangkan peraturan Undang-undang pekerjaan yang merugikan jaminan spesialis adalah aktivitas off-base yang bergantung pada alasan bahwa salah. (Andrian, 2001).

Pemerintah berkeyakinan bahwa Pemerintah merupakan salah satu penghalang bagi spekulasi untuk masuk ke Indonesia dan karenanya ingin membebaskan beberapa koreksi terhadap pasal-pasal dalam Undang-undang penciptaan lapangan kerja bab ketenagakerjaan jelas mencerminkan inisiatif ini. Misalnya, surat kuasa (PKWT) Pasal 56 UU Ketenagakerjaan pada perjanjian kerja khusus telah ditetapkan dua tahun, dan kemungkinan perpanjangan hingga satu tahun ditetapkan dua tahun. Ini berarti bahwa kontrak jenis ini diadopsi untuk waktu yang lama. Selain itu, ketika tiga tahun telah berlalu, tidak ada kewajiban untuk mengubah situasi pekerja yang dipekerjakan menjadi pekerja tetap (Dewa \& Budiarta, 2019).

Demikian pula, perubahan pengaturan istirahat panjang dalam Pasal 79 yang baru-baru ini diperlukan secara hukum harus didukung dalam hal ada pengaturan dalam pengertian kerja, pengaturan kerja agregat atau pedoman perusahaan. Perluasan jeda yang dulunya merupakan opsi yang diizinkan telah menjadi pilihan. Kedua pasal tersebut menunjukkan semakin berkurangnya kewenangan negara atas undang-undang ketenagakerjaan. Hal-hal yang terkait dengan hubungan bisnis, seperti jangka waktu perjanjian, berakhirnya hubungan kerja yang lama, dan sebagainya, dikembalikan ke sistem pengaturan agregat melalui pemahaman bisnis, pengaturan atau organisasi kerja agregat, khususnya pedoman kerja dan bos. Hal ini jelas mengurangi keamanan buruh, dengan alasan bahwa dalam hubungan yang tidak konsisten antara buruh dan manajer, pemahaman antara buruh dan pengusaha pada umumnya akan merepotkan buruh. Ada begitu banyak artikel kontroversial di Ketenagakerjaan. Tentu saja, bab ini tampaknya menjadi tempat utama perdebatan dalam kontranarasi UU Penciptaan Ketenagakerjaan. Perubahan berbagai ketentuan UU Ketenagakerjaan dengan UU Cipta Kerja bahkan tidak memberikan perlindungan tambahan bagi pekerja, tetapi mengurangi perlindungan. Sebab, sudut pandang yang diadvokasi UU Cipta Kerja adalah untuk kepentingan komersial, bukan untuk kepentingan pekerja (Ferianto \& Darmanto, 2010). 
Tentang beberapa karyawan yang diberhentikan oleh perusahaan PT. Jaya Artha Syandana, mulai dari 55 tahun, 10 orang tidak dapat bekerja karena usia mereka dan kekuatan fisik mereka melemah, yang sangat berbahaya bagi diri mereka sendiri, perusahaan dan orang lain. Oleh karena itu, perusahaan memutuskan kontrak kerja dengan perusahaan untuk mengurangi dampak COVID19. Karena adanya perselisihan antara karyawan dengan perusahaan akibat pemutusan hubungan kerja sebelum berakhirnya kontrak, maka perusahaan memberikan perlindungan hukum bagi karyawan yang diberhentikan dan bersedia bertanggung jawab atas karyawan yang diberhentikan tersebut. PT. Jaya Artha Syandana memberikan perlindungan hukum kepada karyawannya seperti perlindungan keselamatan dan kesehatan kerja. Jika terjadi kecelakaan kerja, perusahaan akan memberikan bantuan sampai pemeriksaan berlanjut. Selain itu juga memberikan perlindungan terkait upah, jam kerja dan tahun 2003 tentang Sumber Daya Manusia Tunjangan yang diatur dalam Pasal 86 dan Pasal 88 UU No. 13 tidak hanya berlaku bagi karyawan. Namun, semua itu hanya dapat diberikan jika ada hubungan kerja antara karyawan dengan perusahaan.

Karyawan PT selama ini. Jaya Artha Syandana pernah mengalami masalah pekerjaan akibat Covid-19, namun belum pernah ke pengadilan dan sebagian besar diselesaikan melalui jalur keluarga. Banyak karyawan yang belum mendapatkan haknya (Wawancara ini dilakukan dengan I Ketut Suwitra sebagai karyawan PT. Jaya Artha Syandhana). Isu perlindungan tenaga kerja dalam implementasinya masih jauh dari harapan. Fakta ini terjadi karena munculnya berbagai ide inovatif. Pencantuman perlindungan hukum terhadap pegawai yang diberhentikan jauh dari harapan, karena perusahaan jarang memenuhi hak-hak setelah pemberhentian yang diatur dalam Undang-undang Nomor 13 Tahun 2003, yaitu Pasal 156 ayat 1, 2, 3 dan 4. Yang memuat hak dan kewajiban karyawan dan aturan pemberhentian karyawan. Pekerja dilindungi hukum dalam menuntut kompensasi dari perusahaan.

\section{SIMPULAN DAN SARAN}

\section{Simpulan}

Dari hasil analisis data, dapat disimpulkan bahwa pembuatan kontrak bisnis diatur dalam UU Ketenagakerjaan pada dasarnya bersifat cukup luas. Saat membuat kontrak kerja, kondisinya serupa, untuk lebih spesifiknya tidak boleh bertentangan dengan pedoman organisasi, pengaturan kerja agregat, dan Undang-undang dan pedoman material. Pengaturan ini menyiratkan bahwa dengan asumsi organisasi yang sekarang memiliki pedoman kerja keseluruhan, substansi kontrak kerja, baik dari segi kualitas dan jumlah, tidak boleh sama persis dengan pedoman organisasi saat ini atau pemahaman kerja keseluruhan dari organisasi yang bersangkutan. Pemutusan hubungan kerja menimbulkan akibat hukum baik bagi pemberi kerja maupun pekerja. Akibat hukum yang dimaksud adalah memberikan ganti rugi kepada pekerja atau buruh harian yang telah diberhentikan kerja dengan majikan. Pengusaha wajib memberikan kompensasi kepada pekerja atau pekerja yang telah diputuskan hubungan kerja. Di sisi lain, pekerja atau buruh harian berhak atas kompensasi tersebut. Di PT. Jaya Artha Syandana sebenarnya memberikan perlindungan hukum kepada karyawan terkait keselamatan dan kesehatan kerja. Jika terjadi kecelakaan kerja, perusahaan akan membantu sampai pemeriksaan dilanjutkan. Selain itu juga memberikan perlindungan terkait pengupahan, Pasal 86 dan Pasal 88 Tahun 2003 UU No. 13 tentang Ketenagakerjaan tidak hanya berlaku bagi karyawan. Namun semua itu hanya terjadi bila ada hubungan kerja antara karyawan dengan perusahaan.

\section{Saran}

Adapun saran yang diberikan peneliti berkaitan dengan simpulan penelitian di atas yaitu diharapkan kepada pemerintah dapat menyusun kebijakan terbaik untuk membuat aturan kontrak kerja terutama dalam menghadapi merebaknya virus corona baru dengan dukungan seluruh lapisan masyarakat, menjaga prosedur kesejahteraan dan konsisten mengikuti imbauan otoritas publik untuk menghindari kemacetan dan mengurangi penyebaran wabah infeksi Covid-19 ini. Pelaku usaha dan masyarakat yang melaksanakan PKWT untuk tetap memberikan hak-hak pekerja sesuai dengan peraturan perundang-undangan yang berlaku. Saat melakukan PHK, pengusaha harus lebih memperhatikan hakhak yang harus diperoleh pekerja atau buruh akibat konsekuensi dari PHK. Dalam UU No. 13 Tahun 2003 juga diatur hak yang diberikan kepada pekerja atau buruh yang mengalami pemutusan hubungan kerja, yaitu Pasal 156 sampai dengan Pasal 172. 


\section{DAFTAR PUSTAKA}

Abdul, K. (2014). Dasar-dasar Hukum Ketenagakerjaan. PT.Citra Aditya Bakt: Bandung.

Andrian, S. (2001). Hukum Perburuhan. Sinar Grafika: Bandung.

Dewa, A., \& Budiarta, I. N. (2019). Teori Hukum. Setara Press: Malang.

Dewi, L. P. A. S., Darmadha, I. N., \& Mudana, I. N. (2013). Pelaksanaan Perjanjian Kerja Waktu Tertentu (PKWT)pada Money Changer PT. Dinar Artha Kencana di Ubud Bali. Jurnal Kertha Semaya, 1(10).

Ferianto, \& Darmanto. (2010). Himpunan Putusan Mahkamah Agung dalam Perkara PHI Pemutusan Hubungan Kerja (PHK) Diserta Ulasan Hukum. PT Raja Grafindo Persada: Jakarta.

Maslikan, \& Sukarmi. (2018). Kewenangan Notaris dalam Pembuatan Akta Otentik Berkaitan dengan Kontrak Kerjasama. Jurnal Akta, 5(1), 11-16.

Moleong, L. J. (2005). Metode Penelitian Kualitatif. Remaja Rosdakarya.

Ramlan, \& Fitri, R. R. (2020). Perlindungan Hukum Bagi Tenaga Kerja Dari Tindakan PHK Perusahaan di Masa Covid-19. Jurnal Ilmu Hukum, 8(2), 58-73.

Sendjun, M. (2001). Pokok-pokok Hukum Ketenagakerjaan di Indonesia,. Rineka Cipta: Jakarta.

Wahid, U., \& Puspita, A. E. (2017). Upaya Peningkatkan Brand Awareness PT. Go-Jek Indonesia Melalui Aktivitas Marketing Public Relations. Jurnal Komunikasi, 9(1), 31-41. 